\title{
Effect of a BK viruria reaction detected by qualitative polymerase chain reaction on the renal function of kidney transplant recipients
}

\author{
MING-CHANG HSIEH ${ }^{1,2}$, CHING-WEN HUNG ${ }^{2}$, HUI-LING CHIOU ${ }^{2,3}$ and SHUN-FA YANG ${ }^{1,4}$ \\ ${ }^{1}$ Institute of Medicine, ${ }^{2}$ Department of Clinical Laboratory, ${ }^{3}$ School of Medical Laboratory and Biotechnology, ${ }^{4}$ Department of \\ Medical Research, Chung Shan Medical University and Chung Shan Medical University Hospital, Taichung, Taiwan, R.O.C.
}

Received November 19, 2012; Accepted January 30, 2013

DOI: $10.3892 / \mathrm{mmr} .2013 .1334$

\begin{abstract}
The number of end stage renal failure patients receiving hemodialysis or peritoneal dialysis in Taiwan is on the increase. Of the various treatment options, kidney transplantation is considered to be the ultimate choice, however, it may lead to certain complications, including the infection or reactivation of the $\mathrm{BK}$ virus (BKV). Such viral complications may cause nephritis of the donated kidney and eventually dysfunction and transplantation failure. Therefore the early detection of BKV may be beneficial for kidney transplant recipients. The aim of the present study was to demonstrate the impact of BKV infection on renal function and to show the feasilibility of urine qualitative polymerase chain reaction (PCR) as a screening test in renal transplantation patients. A total of 250 patients were screened for the presence of BKV or John Cunningham virus (JCV) DNA in the urine via qualitative PCR. Subjects positive for urine screening were then further tested using blood sampling. The results showed that 16 patients $(6.4 \%)$ were co-infected by BKV and JCV with a prevalence of 20.4 and $38.4 \%$, respectively. The correlations between viral infection and renal function were further analyzed to show that an infection of BKV has significant effects on the serum creatinine concentration. The mean serum creatinine concentration of the BKV-positive patients was $1.39 \pm 0.09 \mathrm{mg} / \mathrm{dl}$, which was significantly higher than that of the BKV-negative patients $(1.21 \pm 0.03 \mathrm{mg} / \mathrm{dl} ; \mathrm{P}<0.05)$. However, JCV infection has no such effect on renal function. Taken together, these results suggested that PCR monitoring of $\mathrm{BKV}$ with urine samples is a rapid, non-invasive and beneficial method for the prevention of renal complications during the long-term care of kidney transplant recipients.
\end{abstract}

Correspondence to: Professor Shun-Fa Yang, Institute of Medicine, Chung Shan Medical University, 110 Chien-Kuo N. Road, Section 1, Taichung 402, Taiwan, R.O.C.

E-mail: ysf@csmu.edu.tw

Key words: BK virus, renal transplantation, polymerase chain reaction

\section{Introduction}

The BK virus (BKV) is a small, non-enveloped, double-stranded DNA virus with a circular DNA genome of $\sim 5,300$ bp (1). $\mathrm{BKV}$ is a member of the polyomavirus family, consisting of BKV (a major cause of renal allograft dysfunction) $(2,3)$, the John Cunningham virus (JCV; responsible for progressive multifocal leukoencephalopathy) $(4,5)$ and simian virus 40 (SV40). The transmission of BKV occurs mainly via the oral or respiratory route and generally happens in early childhood with only minor symptoms of the upper respiratory tracts or it may even be asymptomatic (6).

BKV may be indefinitely latent in the kidney, urinary tract or lymphoid tissue, therefore this viral infection may be reactivated by immunosuppression and cause several complications, including meninx encephalitis, atypical retinitis, cystitis and tubulointerstitial nephritis (7-10). Since the first case diagnosed by Purighalla et al in 1995 (11), BKV nephropathy (BKVN) has emerged as a significant cause of graft dysfunction (12-14). Early detection of BKV infection within the stages of asymptomatic viuria and viremia has been proposed as a beneficial tool for a preventative treatment against BKVN. Urine cytology has been implemented for screening decoy cells, however, this provides lower positive predictive values and is highly technician-dependent (15). The aim of the present study was to demonstrate the impact of BKV infection on renal function, as well as the feasibility of urine qualitative polymerase chain reaction (PCR) assays as a screening test for BKV infection in renal transplantation patients.

\section{Materials and methods}

Patients and clinical specimens. In total, 250 renal transplant recipients (134 male and 116 female; patient age range, 24-78 years with a mean age of 51.86 \pm 2.1 years) were prospectively enrolled for BKV screening with qualitative PCR at the Chung-Shan Medical University Hospital, Taichung, Taiwan. Urine was collected as midstream samples in a sterile container and blood samples were collected in EDTA tubes. The urine and blood samples were stored at $4{ }^{\circ} \mathrm{C}$ and assayed within 3 days of collection. The urine specimens were centrifuged at 
$105,000 \mathrm{x}$ f for $1 \mathrm{~h}$ and the resultant sediment was re-suspended in $200 \mu \mathrm{l}$ sterilized water. DNA was extracted by the QIAamp ${ }^{\circledR}$ DNA Blood Mini kit (Qiagen, Basel, Switzerland) and eluted with $150 \mu \mathrm{l}$ elution buffer. The blood samples were centrifuged at $1,900 \mathrm{x} \mathrm{g}$ for $5 \mathrm{~min}$ and the DNA was extracted from the plasma using the same protocols. Serum creatinine levels were obtained by an Olympus AU2700 (Olympus Co Ltd., Tokyo, Japan) in the Clinical Laboratory of the Chung Shan Medical University Hospital.

Primers and qualitative PCR. The isolated DNA was amplified by PCR using primers consentaneous for BKV and JCV (F1, 5'-GAT GGC CCC AAC CAA AAG-3' and R1, 5'-CTA GAA CTT CTA CTC CTC C-3'). Following denaturation for 3 min at $95^{\circ} \mathrm{C}$, the PCR reaction was subjected to 30 cycles of $30 \mathrm{sec}$ at $95^{\circ} \mathrm{C}, 30 \mathrm{sec}$ at $40^{\circ} \mathrm{C}$ and $30 \mathrm{sec}$ at $72^{\circ} \mathrm{C}$, followed by a final extension at $72^{\circ} \mathrm{C}$ for $5 \mathrm{~min}$. The amplified products were analyzed by gel electrophoresis with the anticipated size of the amplified product being 110 and $86 \mathrm{bp}$ for BKV and JCV, respectively (Fig. 1).

Statistical analysis. A Student's t-test was used for the statistical analysis involving the continuous variables. $\mathrm{P}<0.05$ was considered to indicate a statistically significant difference.

\section{Results}

Patient characteristics and effect of $B K V$ on serum creatinine concentration levels. The demographic data on the renal transplant recipients are shown in Table I. Of the 250 patients, 134 were male and 116 were female. The patient age ranged from 24 to 78 years (mean age, $51.86 \pm 2.1$ years). According to the results of the PCR screening, 51 (20.4\%) and 96 patients (38.4\%) were positive for BKV and JCV, respectively, while 119 patients $(47.6 \%)$ were negative for the viruses together and 16 patients $(6.4 \%)$ were co-infected by BKV and JCV. Based on their infection status, the patients were categorized into 4 groups and analyzed for the correlations between viral infection and renal function. As shown in Table I, BKV had a significant impact on serum creatinine concentration as the mean serum creatinine concentration of patients positive for only BKV was $1.39 \pm 0.09 \mathrm{mg} / \mathrm{dl}$, which was significantly higher than that of patients negative for the two viruses $(1.21 \pm 0.03$; $\mathrm{P}<0.05$; Fig. 2A). This effect existed for each gender. In contrast, JCV infection had no or only a slight effect on renal function.

Infection status of patients. With regard to further blood screening in the patients with BKV viuria, the patients were grouped based on their BK infection status into BKV-negative (199 patients, 79.6\%), BKV viuria (43 patients, $17.2 \%$ ) and BKV viuria/viremia (8 patients, $3.2 \%$ ) groups (Table II). However, there was no significant difference in the serum creatinine concentration between the BKV-negative $(1.24 \pm 0.02 \mathrm{mg} / \mathrm{dl})$ and $\mathrm{BKV}$ viuria/viremia groups $(1.39 \pm 0.23 \mathrm{mg} / \mathrm{dl} ; \mathrm{P}=0.241$; Fig. $2 \mathrm{~B})$. Overall, the results suggested that PCR monitoring of BKV with urine samples was a rapid, non-invasive and beneficial method for the long-term care of kidney transplant recipients. This aids in our understanding of the significance of looking after kidney transplant patients that have been infected by BKV.

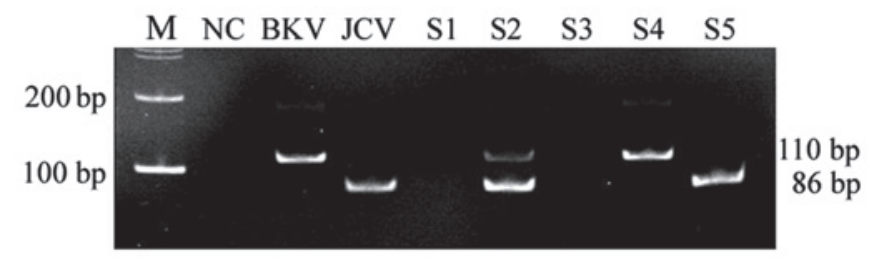

Figure 1. Gel electrophoresis of the PCR amplified product. S1 was negative; $\mathrm{S} 2$ was BKV-positive/JCV-positive; S3 was negative; S4 was BKV-positive; S5 was JCV-positive. M, 100 bp marker; NC, negative control; BKV, positive control; JCV, positive control; S, sample; PCR, polymerase chain reaction, $\mathrm{BKV}, \mathrm{BK}$ virus, $\mathrm{JCV}$, JC virus.
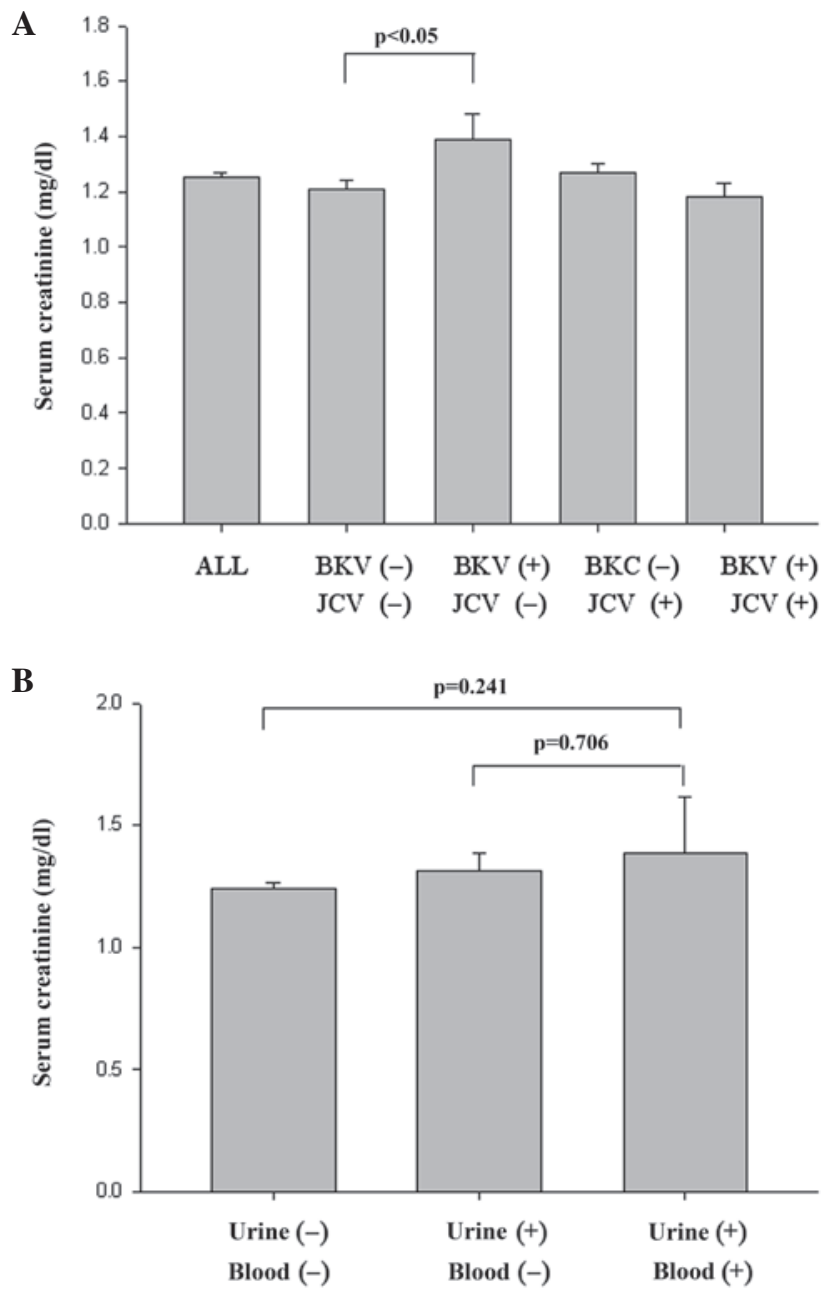

Figure 2. Mean serum creatinine levels in the renal transplantation patients with varying statuses of viral infection. (A) All patients $(n=250)$ : Group I, patients negative for the two viruses $(\mathrm{n}=119)$; group II, patients positive for only BKV ( $\mathrm{n}=35)$; group III, patients positive for only JCV $(\mathrm{n}=80)$; and group IV: patients positive for BKV and JCV $(\mathrm{n}=16)$. (B) BKV-negative in urine and blood ( $n=199)$; BKV-positive in urine but negative in blood $(n=43)$; $\mathrm{BKV}$-positive in urine and blood ( $\mathrm{n}=8)$. BKV, BK virus; $\mathrm{JCV}$, JC virus.

\section{Discussion}

Although numerous studies $(12,14)$ in recent years have explored the reasons behind post-kidney transplant complications, the majority extracted the patients' blood for virus detection and extremely few performed virus detection 

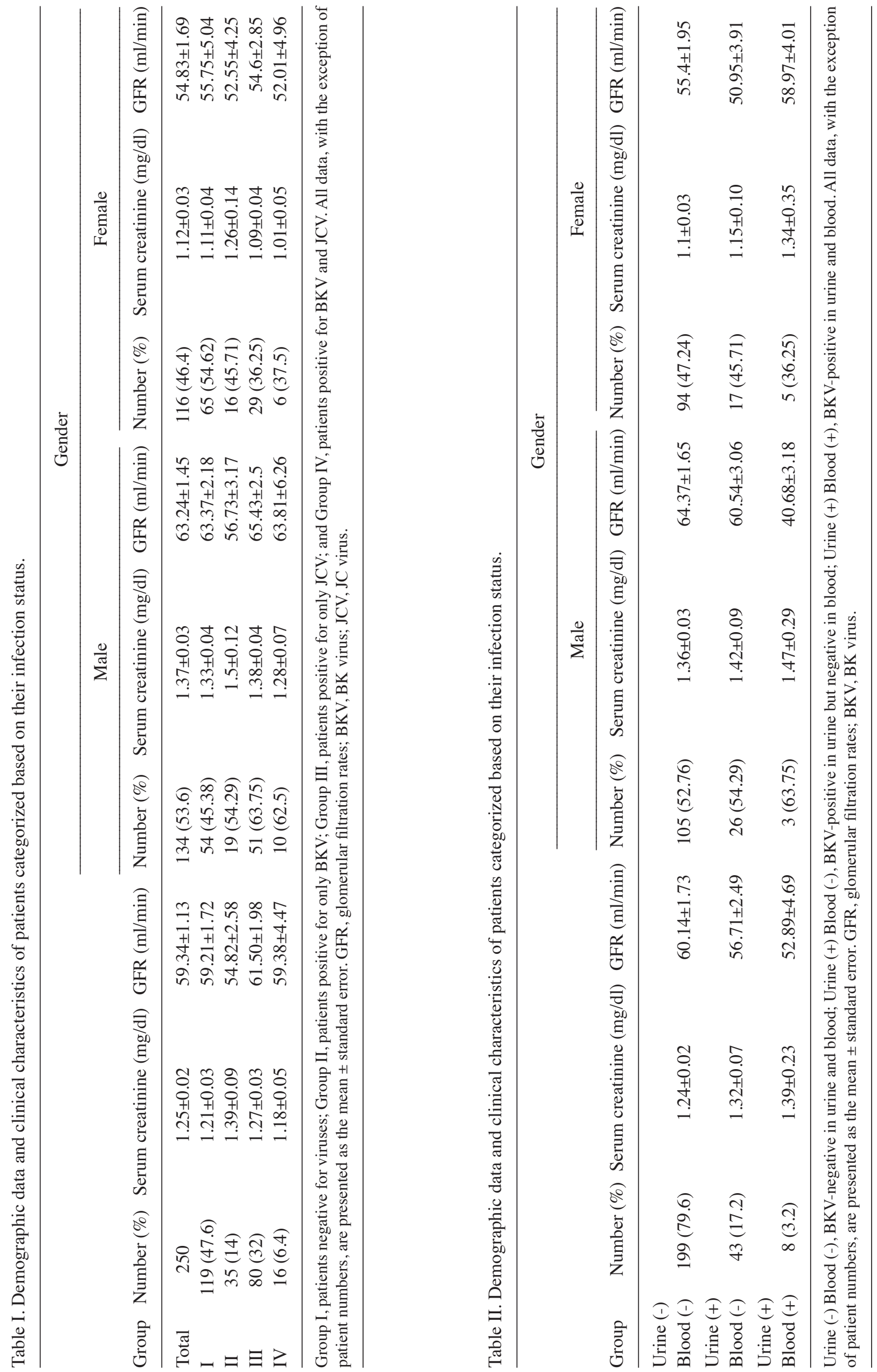
based on the patients' urine. Therefore, the present study established a viable detection method and sought to provide valid data references for clinicians more rapidly. Subsequent to ultracentrifugation $(105,000 \mathrm{x} \mathrm{g,} 1 \mathrm{~h})$ of the urine specimens obtained from the 250 kidney transplant patients, DNA was extracted for PCR analyses to assess whether polyomavirus (BKV or JVC) infections had occurred. The results showed that the blood serum creatinine concentrations for the kidney transplant patients without any viral infections and for those patients with the BKV infection only were $1.21 \pm 0.03$ and $1.39 \pm 0.09 \mathrm{mg} / \mathrm{dl}$, respectively, thus exhibiting a significant difference $(\mathrm{P}<0.05)$. This result indicated that for this group of kidney transplant patients, the development of a BKV infection would lead to kidney damage and decreasing kidney function. Therefore, early detection of the BKV virus was extremely beneficial for the patients.

Generally, post-transplant diabetes mellitus (PTDM) occurs within 3 months of transplantation (16). The results of the present study showed that from the 250 participating kidney transplant patients, no significant statistical difference was observed between the blood serum creatinine concentrations and glomerular filtration rates (GFRs) of the patients without viral infection, with BKV infection only, with JCV infection only or with BKV and JCV infection under the conditions of no diabetes mellitus (N-DM), diabetes mellitus (DM) or PTDM. Although previous studies have indicated that the occurrence of PTDM is generally related to the use of immunosuppressants following kidney transplantation $(17,18)$, the patients with viral infections and PTDM in the present study were limited and the results were not comparable any further.

The clinical BKV nephropathy detection method currently applied requires the patients' blood serum creatinine $(\mathrm{mg} / \mathrm{dl})$ concentration to reach a certain level, indicating that conditions are already poor. The method also requires decoy cells to be identified through urine cytology tests prior to performing kidney biopsy confirmation, which requires a longer period of time $(19,20)$. In the present study, DNA detection was directly performed using the patients' urine. Through electrophoresis analysis, the results obtained using the two centrifugation methods were observed to be identical. Besides providing patients with earlier and more rapid test results, the method of the present study also provides a faster reference for clinicians to administer appropriate immunosuppressant treatments to patients, reducing the likelihood of BKV infections damaging the functions of the transplanted kidney.

During the present study, a noteworthy situation was also observed. When comparing the conditions for the kidney transplant patients infected with the two viruses, the blood serum creatinine concentrations for the patients without viral infection and for the patients with BKV infection only were $1.21 \pm 0.03$ and $1.39 \pm 0.09 \mathrm{mg} / \mathrm{dl}$, respectively, thus exhibiting a significant difference $(\mathrm{P}<0.05)$. Following $\mathrm{BKV}$ infection, the blood serum creatinine concentrations increased. However, in the patients co-infected with BKV and JVC, the blood serum creatinine concentration was $1.18 \pm 0.05 \mathrm{mg} / \mathrm{dl}$ and had decreased, exhibiting a level that was an improvement on that of the patients without infections. Whether this means that $\mathrm{JCV}$ infection is able to inhibit the effects of BKV infection or not is worthy of investigation. Currently, JCV infection is considered to only affect the central nervous system $(21,22)$; thus, few studies have explored its effects on the kidneys. Therefore, further investigations and comparisons of the interaction and effects of JCV and BKV during coinfection are worth pursuing.

Finally, the results of the present study have shown that the extraction of DNA directly from the urine for PCR detection is critical for kidney transplant patients. This method is able to provide earlier detection of BKV viral infections, allow prompt administration of appropriate immunosuppressant treatments among patients and reduce the likelihood of BKV infections damaging the functions of the transplanted kidney. Additionally, urine cytology observations and blood BKV viral infection detection may be combined with biopsies and immunohistochemical staining to confirm BKV nephropathy and provide the most effective treatment and assistance to patients who have received a kidney transplant.

\section{Acknowledgements}

This study was supported by Chung Shan Medical University Hospital (CSH-97-A-12), Taichung, Taiwan.

\section{References}

1. Eash S, Manley K, Gasparovic M, Querbes W and Atwood WJ: The human polyomaviruses. Cell Mol Life Sci 63: 865-876, 2006.

2. Gardner SD, Field AM, Coleman DV and Hulme B: New human papovavirus (B.K.) isolated from urine after renal transplantation. Lancet 1: 1253-1257, 1971.

3. Padgett BL, Walker DL, ZuRhein GM, Eckroade RJ and Dessel BH: Cultivation of papova-like virus from human brain with progressive multifocal leucoencephalopathy. Lancet 1: 1257-1260, 1971.

4. Zu Rhein G and Chou SM: Particles resembling papovaviruses in human cerebral demyelinating disease. Science 148: 1477-1479, 1965.

5. $\mathrm{Zu}$ Rhein GM: Polyoma-like virions in a human demyelinating disease. Acta Neuropathol 8: 57-68, 1967.

6. Goudsmit J, Wertheim-van Dillen P, van Strien A and van der Noordaa J: The role of BK virus in acute respiratory tract disease and the presence of BKV DNA in tonsils. J Med Virol 10: 91-99, 1982.

7. Moret H, Guichard M, Matheron S, et al: Virological diagnosis of progressive multifocal leukoencephalopathy: detection of JC virus DNA in cerebrospinal fluid and brain tissue of AIDS patients. J Clin Microbiol 31: 3310-3313, 1993.

8. Sundsfjord A, Spein A, Lucht E, Flaegstad T, Seternes OM and Traavik T: Detection of BK virus DNA in nasopharyngeal aspirates from children with respiratory infections but not in saliva from immunodeficient and immunocompetent adult patients. J Clin Microbiol 32: 1390-1394, 1994.

9. Chesters PM, Heritage J and McCance DJ: Persistence of DNA sequences of BK virus and JC virus in normal human tissues and in diseased tissues. J Infect Dis 147: 676-684, 1983.

10. Elsner C and Dörries K: Evidence of human polyomavirus BK and JC infection in normal brain tissue. Virology 191: 72-80, 1992.

11. Purighalla R, Shapiro R, McCauley J and Randhawa P: BK virus infection in a kidney allograft diagnosed by needle biopsy. Am J Kidney Dis 26: 671-673, 1995.

12. Chen $\mathrm{CH}$, Wen $\mathrm{MC}$, Wang $\mathrm{M}$, et al: A regulatory region rearranged $\mathrm{BK}$ virus is associated with tubulointerstitial nephritis in a rejected renal allograft. J Med Virol 64: 82-88, 2001.

13. Petrogiannis-Haliotis T, Sakoulas G, Kirby J, et al: BK-related polyomavirus vasculopathy in a renal-transplant recipient. $\mathrm{N}$ Engl J Med 345: 1250-1255, 2001.

14. de Bruyn G and Limaye AP: BK virus-associated nephropathy in kidney transplant recipients. Rev Med Virol 14: 193-205, 2004.

15. Boldorini R, Brustia M, Veggiani C, et al: Periodic assessment of urine and serum by cytology and molecular biology as a diagnostic tool for BK virus nephropathy in renal transplant patients. Acta Cytol 49: 235-243, 2005. 
16. Kasiske BL, Snyder JJ, Gilbertson D and Matas AJ: Diabetes mellitus after kidney transplantation in the United States. Am J Transplant 3: 178-185, 2003.

17. Boudreaux JP, McHugh L, Canafax DM, et al: The impact of cyclosporine and combination immunosuppression on the incidence of posttransplant diabetes in renal allograft recipients. Transplantation 44: 376-381, 1987.

18. Sumrani NB, Delaney V, Ding ZK, et al: Diabetes mellitus after renal transplantation in the cyclosporine era - an analysis of risk factors. Transplantation 51: 343-347, 1991.
19. Cimbaluk D, Pitelka L, Kluskens L and Gattuso P: Update on human polyomavirus BK nephropathy. Diagn Cytopathol 37: 773-779, 2009

20. Hariharan S: BK virus nephritis after renal transplantation. Kidney Int 69: 655-662, 2006.

21. Studahl M: Influenza virus and CNS manifestations. J Clin Virol 28: 225-232, 2003

22. Khalili K, Gordon J and White MK: The polyomavirus, JCV and its involvement in human disease. Adv Exp Med Biol 577: 274-287, 2006 